\title{
天井クレーンにおけるパワーアシストシステムの構築*
}

$$
\text { 三好孝 典*1, 鈴木 裕 一*2, 寺嶋一彦*3 }
$$

\section{Construction of Power Assist System for Overhead Crane}

\author{
Takanori MIYOSHI*4, Yuichi SUZUKI and Kazuhiko TERASHIMA \\ ${ }^{* 4}$ Faculty of Engineering, Toyohashi University of Technology, \\ 1-1 Hibarigaoka, Tempaku-cho, Toyohashi-shi, Aichi, 441-8580 Japan
}

\begin{abstract}
In this paper, a power assist system for an overhead crane is presented. This system is realized by measuring the swing angle of a crane, which is caused by the direct operation to the object, and by moving the trolley and girder in the desired direction. Operators can move a heavy object freely by slight force. In this paper, two kinds of controllers are proposed. One is a PD controller that emulates the dynamics of object with damping and it moves the object in proportional velocity to the operating force in steady-state. Another is a PID controller that maintains the velocity of object continuously after operators cease their force. Its dynamics, damping characteristics, steady-state and admissible condition of controller gain are discussed. This system is applied to an experimental overhead crane, and the effect of energy saved by the power assist is shown by measuring the heart rate of operator.
\end{abstract}

Key Words: Motion Control, Human Interface, Vibration Control, Power Assist System, Overhead Crane

\section{1. 緒 言}

通常, 生産現場においては重量物の搬送, 位置決め は天井クレーンなどの機械を用いて行われている.し かし, 従来の操作パネルによる搬送では, 荷物の正確 な位置決めが難しく、繰り返しのボタン操作を必要と することから作業が効率的ではない, あるいは荷振れ を抑制するためには作業者の熟練が必要である, など の問題点を抱えている. このため一部工程では, 手で 直接重量物を取り扱う作業がしばしば行われており, 作業者の身体的疲労, 精神的負担が大きな問題となっ ている. この問題を解決するために，搬送の完全自動 化が図られてはいるが, さまざまな環境, 刻々と変わ る作業現場に対応するにはまだ不十分である. そこで 本論文では, 人間の高度な状況判断能力を活かしなが ら, なおかつ作業者の負担を軽減する方策として, 重 量物を直接手で取り扱いながらもわずかな力で搬送で き，作業者の意図どおりの微細な位置決めを可能にす るパワーアシストシステムを提案する.

従来, クレーンの操作支援の研究は, 作業者がク

$*$ 原稿受付 2003 年 9 月 1 日.

*1 正員, 豊橋技術科学大学工学部 ( $-441-8580$ 豊橋市天伯町 雲雀ヶ丘 1-1).

*2 (株) 近藤製作所 ( 443-0036 蒲郡市浜町 73-4)

*3 正員, 豊橋技術科学大学工学部.

E-mail : miyoshi@ procon.tutpse.tut.ac.jp
レーンを動かす際の制振制御や安全確保に重点を置 き, 作業者の精神的ストレスの軽減や作業時間の短縮 を目的とした研究が多い. 山本らはジョイスティック から得られた速度指令を荷振れのない吊り荷軌道に変 換し, 逆動力学計算を用いて, システムの入力を求め る研究 ${ }^{(1)(2)}$ を行い, 鈴木らはフィードバック制御によ り荷振れを抑制した上で, あらかじめ障害物情報を把 握しておくことで作業者が操作パネルの操作ミスを起 こした場合でも安全を保障するシステム ${ }^{(3)}$ を構築し ている. また, 高木らはフィルタによる波形整形で作 業者からの任意指令に対する制振効果を得ている ${ }^{(4)}$. しかし,これらにより荷振れは抑制できるものの, い ずれもジョイスティックなどの機械要素を経由した間 接的な操作支援であるため, 荷物の位置決め精度の問 題や位置決めに要する作業時間, 精神的ストレスなど に課題が残る.

身体的負荷の軽減を図るパワーアシストシステムの 研究としては, 既に実用化されたものに関連する研究 として, 前田らの給仕台車 ${ }^{(5)}$ や蒦下らの電動自転車 における走行抵抗の制御 ${ }^{(6)}$ などが知られている. ま た福祉分野では, 藤江らの歩行補助器 ${ }^{(7)}$ や西坂らの 全方向移動車椅子のパワーアシスト制御の研究 ${ }^{(8)}$ が 行われている. しかし, 従来の研究はいずれも十分に 剛性のある装置を研究対象としており, 得られた知見 
をクレーンのような共振を有する柔軟構造物にそのま ま適用することはできない，一方，本論文のように工 場内の搬送を想定した研究として, 中村ら ${ }^{(9)}$ は力覚 センサを用いて人間の操作力を測定し，その力に応じ たアシスト力を得ており, 山田ら ${ }^{(10)}$ のスキルアシス トは作業負担の軽減だけでなく操作フィーリングも考 慮している.さらに海外ではアクセルとハンドルによ り人間が操作する СOBOT $^{(11)}$ が開発されている.し かし，これらはいずれも操作量を測定するセンサが荷 物とは別の場所に設置してあるため, 荷物に直接触れ ながら搬送をすることができず，良好な操作感覚が期 待できない.また, いずれにおいても力学的, 制御的 な特性が工学的に明らかにされておらず, パワーアシ ストの効果も明確ではない.さらに, 設備に関してパ ワーアシストシステム専用の装置が必要であり, 工場 への導入に課題が残る.

以上のことから, 本研究では, 柔軟構造物に対する パワーアシストシステムを提案し, 工学的特性および 負担軽減の定量的な効果を論文内で明らかにする．本 システムは作業者が荷物を直接手で操作できる点と, 社会に数多く普及しているクレーンシステムを対象と している点に大きな特徴を有する.

\section{2. パワーアシストシステムの機構}

本研究で用いるパワーアシストシステムの機構を図 1 亿示す. 通常の天井クレーンの実験機を改良したも ので, ガーダー（X 軸）とトロリー（Y 軸）は独立に $\mathrm{AC}$ サーボモータで駆動され, パワーアシストは $\mathrm{X}, \mathrm{Y}$ 平面において実現される．それぞれの位置は ACサー ボモータ内のエンコーダにより計測される. Z 軸方向 の荷物の上げ下げは DC サーボモータにより駆動され るが, 押しボタンにより操作される. 荷物の振れ角は 図2のような構造により測定される.すなわち，X-Z 平面における振れ角度 $\alpha[\mathrm{rad}]$, および Y-Z 平面におけ る振れ角度 $\beta[\mathrm{rad}]$ はロープを両側からフォークで挟 み, このフォークの動きをロータリーエンコーダで計 測する.

システムへの入力は各 $\mathrm{AC}$ サーボコントローラへの 速度指令值であり, 出力は各軸の振れ角度である. AC サーボコントローラは, トルクの飽和範囲内であれば 荷物の重量に関わらず, ガーダーとトロリーを指令さ れたとおりの速度に制御できるものとする. 以降，本 論文ではガーダーとトロリーをともに台車と呼ぶ.

\section{3. パワーアシストコントローラの設計}

$3 \cdot 1$ ダイナミクスのモデル化＼cjkstart簡単のため, 高 次モードの振動成分を持たないとした 1 軸分のパワー

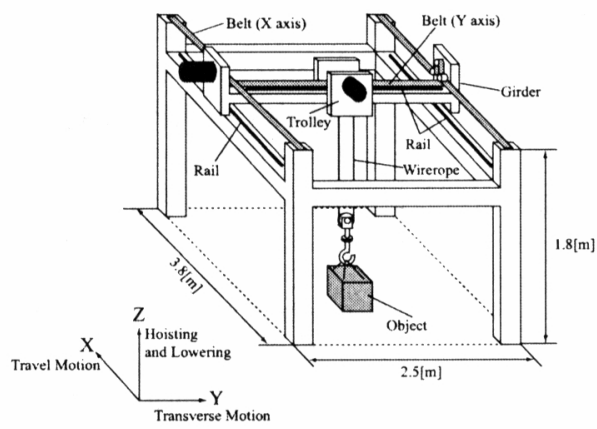

Fig. 1 Experimental Apparatus of overhead crane

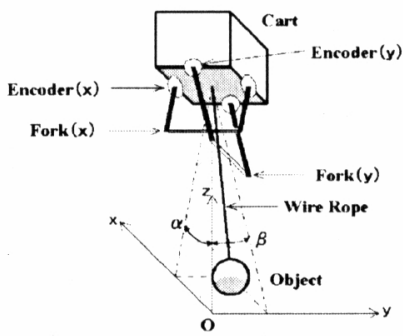

Fig. 2 Mesurement apparatus for swing angle

アシストシステムのモデルを図 3 に示す. 実際は 2 軸 の動作が合成されるが, 振れ角度が小さければ振れと 各台車の運動は各軸独立の微分方程式で表すことがで きる.

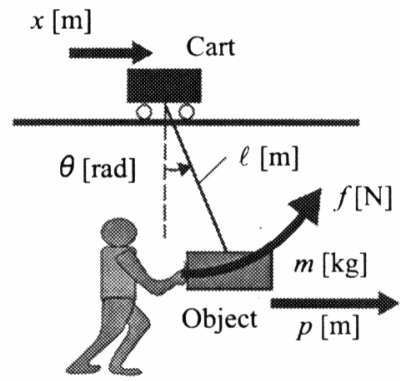

Fig. 3 1-DOF dynamic model of power assist

図において，運動方程式は以下のように表される.

$$
\left\{\begin{array}{c}
m \ell^{2} \ddot{\theta}+m \ell \ddot{x} \cos \theta+m \ell g \sin \theta+D_{\theta} \dot{\theta}=f \ell \\
p=x+\ell \sin \theta
\end{array},\right.
$$

ここで, $m[\mathrm{~kg}]$ : 荷物の質量, $\ell[\mathrm{m}]$ :ロープ長, $\theta[\mathrm{rad}]$ : 振れ角, $x[\mathrm{~m}]$ :台車の位置, $D_{\theta}[\mathrm{Nm} / \mathrm{s}]$ : 粘性抵抗, $f[\mathrm{~N}]$ :作業者によって与えられる操作力, $p[\mathrm{~m}]$ : 荷物の位置 である. 操作力 $f$ は $\theta$ 軸周りに加えられるものとする. 
3.2 フィードパックシステムの原理＼cjkstart本システ ムの制御ブロックは以下のように表される.

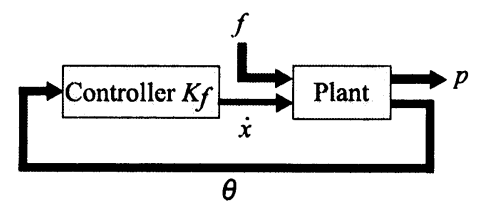

Fig. 4 Block diagram of control system

作業者が操作力を荷物に加えるとき，振れ角 $\boldsymbol{\theta}$ が 生じる. 台車速度の指令值 $\dot{x}$ をフィードバックゲイン $K_{f}$ を用いて $\dot{x}=K_{f} \theta$ によって与えるならば, $K_{f}$ を大 きくすることによって，作業者はわずかな力で重量物 をより早い速度で搬送することができる．この原理は 従来のパワーアシストとは思考が異なっており，した がってアシスト率という概念は存在しない. このコン トローラを X,Y 軸にそれぞれ組み込むことで, 作業者 は荷物を直接手に持ち, $\mathrm{X}, \mathrm{Y}$ 平面上を自由に移動させ

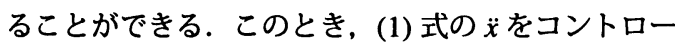
ラの出力で置き換えると以下のように線形化できる.

$$
\left\{\begin{array}{c}
m \ell^{2} \ddot{\theta}+\left(m \ell K_{f}+D_{\theta}\right) \dot{\theta}+m \ell g \theta=f \ell \\
p=x+\ell \theta
\end{array}\right.
$$

$K_{f}$ を比例ゲイン $K_{p}$, 積分ゲイン $K_{i}$, 微分ゲイン $K_{d}$ の PID コントローラ $K_{f}=K_{p}+K_{d} s+\frac{K_{i}}{s}$ とすると, ラ プラス変換された操作力 $F(s)$, 荷物位置 $P(s)$, 振れ 角 $\theta(s)$ の関係は (3) 式のようになる.

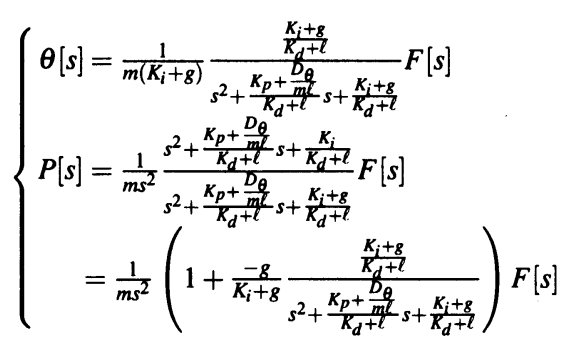

(3) 式の下段括弧内の第一項はエネルギーの散逸のない 環境下における質点の運動を表し, 第二項は $-g /\left(K_{i}+\right.$ $g)$ に収束する過渡応答を表す．比例ゲイン $K_{p}$ と粘性 摩擦 $D_{\theta}[\mathrm{Nm} / \mathrm{s}]$ は共にダンピングの効果をもたらすこ とがわかる.なお，以降では粘性摩擦は十分小さく無 視できるものとして取り扱うが, $K_{p}$ の中に考慮され ていると考えても差し支えない.

3.3 PD コントローラの設計制御則として, $\mathrm{PD}$ 制御 $\left(K_{i}=0\right)$ を採用した場合のシステムの特性, ゲインの制約について考察する.
3.3.1 残留振動に関する検討ＰD コントロー ラにおいて, (3) 式は次のように書き換えられる.

$$
\left\{\begin{array}{l}
\theta[s]=\frac{1}{m g} \frac{\frac{g}{K_{d}+\ell}}{s^{2}+\frac{K_{p}}{K_{d}+\ell} s+\frac{g}{K_{d}+\ell}} F[s] \\
P[s]=\frac{1}{m s} \frac{s+\frac{K_{d}}{K_{d}+\ell}}{s^{2}+\frac{K_{p}}{K_{d}+\ell} s+\frac{g}{K_{d}+\ell}} F[s]
\end{array}\right.
$$

ここで, $\theta[s]$ は減哀定数 $\zeta$ と固有振動数 $\omega_{n}$ を持つ 2 次遅れ系である.

$$
\left\{\begin{array}{l}
\zeta=\frac{K_{p}}{2 \sqrt{\left(K_{d}+\ell\right) g}} \\
\omega_{n}=\sqrt{\frac{g}{K_{d}+\ell}}
\end{array}\right.
$$

なお, 状態方程式で表した場合, 操作力 $f(t)$ と荷物 位置 $p(t)$ の関係は,

$$
\left\{\begin{array}{l}
\dot{x}=A x+B f(t) \\
p(t)=C x \\
A=\left(\begin{array}{cc}
-\frac{K_{p}}{K_{d}+\ell} & -\frac{g}{K_{d}+\ell} \\
1 & 0
\end{array}\right), B=\left(\begin{array}{c}
\frac{1}{m} \\
0
\end{array}\right), C=\left(1, \frac{K_{p}}{K_{d}+\ell}\right)
\end{array}\right.
$$

で与えられる.

パワーアシストシステムにおいて, 荷物の残留振動 は作業者にとって極めて危険である. そこで, 残留振 動を速やかに抑制する臨界制動の条件 $\zeta>1.0$ から, (5) 式より以下のゲインに関する制約条件が得られる. これは微分ゲインとロープ長から定まる比例ゲインの 許容範囲 (下限) を表す.

$$
K_{p} \geq 2 \sqrt{\left(K_{d}+\ell\right) g}
$$

一方, $K_{p}$ の上限は二つの要素により決定される. す なわち, 一つはモデル化されていない高次の振動要素 の影響で第 4.3 節で述べる. もう一つは次項で述べる 速応性の観点からである.

3.3.2 速応性に関する検討作業者にとって使い やすいシステムとは, 荷物への操作に対しシステムが 速やかに応答することである. このことは固有振動数 $\omega_{n}$ を大きくし, システムの周波数帯域を広げること で実現できる. そのためには，(5) 式の $\omega_{n}$ の分母に 着目すると, $K_{d}>-\ell$ の制約下で $K_{d}$ をできる限り負 方向に大きくとればよい. このとき, 微分ゲインが支 配的な過渡応答において, 台車は荷物の振れの反対方 向, すなわち操作力とは反対の向きに動き出すことに なる.これは (2) 式において, 台車の位置 $x$ の伝達関 数が $X[s]=\frac{-K_{d} s-K_{p}}{m g s} \frac{\frac{R_{d}}{K_{d}+\ell}}{s^{2}+\frac{K_{p}}{K_{d}+\ell} s+\frac{g}{K_{d}+\ell}} F[s]$ となり, $K_{d}<0$ のときに非最小位相系になることからも明らかである. 一見矛盾のようであるが, 作業者が前方に荷物を押し 出したとき, 台車はいったん後方にバックしたあと方 
向転換し，前方に進みだす動作が高速応答をもたらす ことになる. 図 5 は, $K_{p}=5.0, m=30.0[\mathrm{~kg}], \ell=1.0[\mathrm{~m}]$ としたときの, $K_{d}=0$ (P制御) と $K_{d}=-0.5$ (PD 制 御）におけるステップ入力の場合の台車の動きを示し たものである. PD 制御の場合は台車がバックするこ とで, 振れ角の立ち上がりが早くなっていることが確 認できる.

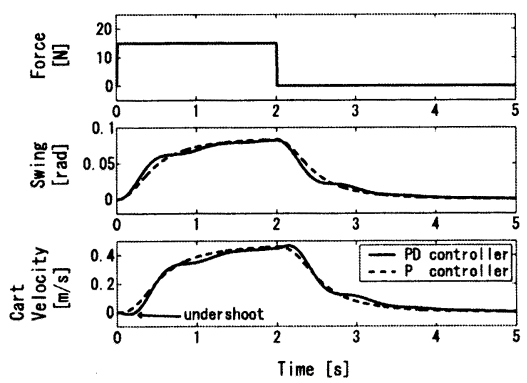

Fig. 5 Backword motion of the cart in the case of $K_{d}<0$

速応性について, さらに2ノルムを用いて詳しく検討 する. (4) 式において荷物の速度 $V[s]=s P[s]=H[s] F[s]$ （ただし $\left.H[s]=\frac{1}{m} \frac{s+\frac{K_{p}}{K_{d}+l}}{s^{2}+\frac{K_{p}}{K_{d}+l} s+\frac{g}{K_{d}+l}}\right)$ に関する操作力のイ ンパルス応答 $h(t)$ の初期值 $h(0)$ は，ゲインに関し不 変で初期值定理より,

$$
h(0)=\lim _{s \rightarrow \infty} s V[s]=1 / m
$$

で与えられる.したがって, $h(t)$ の過渡応答の収束速 度は $h(t)$ の面積の 2 乗和, すなわち 2 ノルムの 2 乗 $\|H\|_{2}^{2}=\int_{0}^{\infty} h(t)^{2} d t に よ っ て$ 評価することができる. な ぜならば, $h(0)$ が不変であることから, $\|H\|_{2}^{2}$ が小さ ければ $h(t)$ は速やかに 0 に収束していると考えられ るからである. もし, $h(0)$ がゲインによって変化する ならば, 収束が遅くても $h(0)$ が小さくなったときに 2 ノルムが減少してしまうため評価に用いることはで きない. また, 通常行われるシステムの根による速応 性の判断は極と同時に零点が変化することから困難で ある.

さて, $\|H\|_{2}$ はリアプノフ方程式の正定解, すなわ ち可制御性グラミアン $P$ を用いて次のように求められ $ろ^{(12)}$.

$$
A P+P A^{T}+B B^{T}=0, \quad\|H\|_{2}=\sqrt{C P C^{T}}
$$

(6) 式の $A, B, C$ を用いることにより, 解析解として

$$
\|H\|_{2}^{2}=\frac{g K_{d}+g \ell+K_{p}^{2}}{2 g m^{2} K_{p}}=\frac{1}{2 m^{2}}\left(\frac{K_{p}}{g}+\frac{K_{d}+\ell}{K_{p}}\right)
$$

を得る. このとき, $\|H\|_{2}^{2}$ を最小にするゲインの関係 式は, $\frac{\partial\|H\|_{2}}{\partial K_{p}}=0$ より,

$$
K_{p}=\sqrt{\left(K_{d}+\ell\right) g}
$$

となり, 最小値は $\min \|H\|_{2}^{2}=\frac{1}{m^{2}} \sqrt{\frac{K_{d}+\ell}{g}}$ となる. しか し, (9) 式は明らかに (7) 式の条件を満たしていない から, 結局, 残留振動を抑え, かつ最も速応性のある ゲインの関係は (7) 式の等号が成り立つ場合で, この とき

$$
\min \|H\|_{2}^{2}=\frac{5}{4 m^{2}} \sqrt{\frac{K_{d}+\ell}{g}}
$$

を得る. 以上の議論から, システムの 2 ノルムの值を 小さくし, 速応性をあげるためには $K_{d}$ として負を選 択し,できるだけ $K_{d}+\ell$ を 0 に近づければよいこと がわかる. 図6に $m=30[\mathrm{~kg}], \ell=1.0[\mathrm{~m}]$ としたときの $\|H\|_{2}^{2}$ の変化およびインパルス応答の変化を示す.
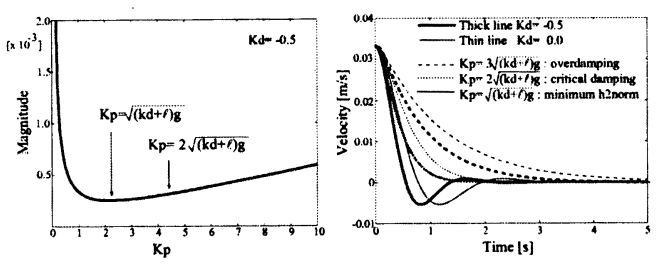

Fig. 6 Variation of $\mathrm{H}_{2}$ norm and impuls response

左図は $K_{p}$ に関する 2 ノルムの変化をグラフ化した もので, (8) 式からもわかるように, 極小值より大き な領域では $\|H\|_{2}^{2}$ はおおよそ $K_{p}$ に比例して大きくな る. 右図は $K_{d}$ が-0.5 (太線) と 0 (細線) の場合のそ れぞれ異なった 3 種類の $K_{p}$ によるインパルス応答を 示したもので, $K_{d}$ を負にとり適切な $K_{p}$ を選択するこ とで, 振動のない速やかな荷物速度の収束が実現でき ることが確認できる. 通常, 速応性をあげるためには 比例ゲインを大きくとることが行われるが, 本システ ムでは $K_{p}$ を上げると速応性は失われる.

なお， $K_{p}$ を大きくすることはシステム応答の鈍化 をもたらすことは根軌跡の観点からも明らかである.

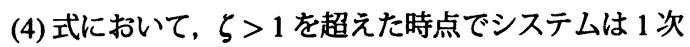
遅れの組み合わせとなり， $K_{p}$ の増加に伴って代表極 は低周波の方向に移動する.

\subsection{3 定常状態の特性 (4)式より, 本パワーア} シストシステムに一定の操作力 $f$ が加え続けられたと きの荷物の挙動の定常状態は, 以下の式で表される速 度 $V_{0}$ に整定する.

$$
V_{o}=\frac{K_{p}}{m g} f
$$


これは, 粘性 $m g / K_{p}[\mathrm{Ns} / \mathrm{m}]$ の摩擦のない環境下に おける質点の運動と等速であり, 操作力 $f$ と $K_{p}$ に比 例した速度で荷物が移動することを表す．すなわち， 作業者の負担を減らすためには, できるだけ $K_{p}$ を大 きく選択すれば良いことを示している，定常状態にお ける仕事率 $\mathrm{W}[\mathrm{J} / \mathrm{s}]$ は, $W=\frac{K_{p}}{m g} f^{2}$ で与えられることか ら, 仕事率と前項で議論された速応性はトレードオフ の関係となる. すなわち, 速応性はおおよそ $K_{p}$ に比 例して悪化し，仕事率は $K_{p}$ に比例して向上する. 結 局, コントローラの設計の目安としては, 小刻みな位 置決めや細かな繰り返し作業が多い場合は $K_{p}$ を小さ くし, 長距離搬送や重量物の場合は $K_{p}$ を大きくする とよい. なお, ロープ長やゲイン $K_{d}$ は定常的な仕事 率に影響を与えない.

3.4 PID コントローラの設計 制御則として PID 制御を採用した場合のシステムの特性, ゲインの 制約について以下に示す.

3.4.1 残留振動に関する検討第 3.3 節と同様 の議論によって, (3)式から残留振動を抑制するための 制約条件が求められる.これは微分ゲイン, 積分ゲイ ンおよびロープ長から定まる比例ゲインの下限を示す.

$$
K_{p}>2 \sqrt{\left(K_{d}+\ell\right)\left(K_{i}+g\right)}
$$

3.4 .2 定常状態の特性

(3) 式より, 本パワーア シストシステムに操作力 $f$ が加えられたときの荷物の 加速度の定常状態は, 以下の式で表される加速度 $A_{0}$ に整定する.これは, 摩擦のない環境下における質量 $m\left(1+\frac{8}{K i}\right)$ の質点の運動と等価である.

$$
A_{0}=\frac{1}{m} \frac{K_{i}}{K_{i}+g} f
$$

さらに, 有限の時刻 $T[\mathrm{~s}]$ で 0 に収束する力 $f(t)$ $(T<t$ で $f(t)=0)$ を加えたときの荷物の速度の定 常状態は，以下の式で表される速度 $V_{0}$ に整定する.

$$
V_{0}=\frac{1}{m} \frac{K_{i}}{K_{i}+g} \int_{0}^{T} f(t) d t
$$

なぜならば, (3) 式より, 最終值定理から,

$$
V_{0}=\lim _{s \rightarrow 0} s V[s]=s^{2} P[s]=\frac{1}{m} \frac{K_{i}}{K_{i}+g} \lim _{s \rightarrow 0} F[s]
$$

を得, 付録より (14) 式が求められる.これは, 荷物の 移動速度は操作力の積分により決定されるとともに, 操作力が除去された後も運動を維持することを意味す る. それゆえ, 本 PID コントローラは作業者の負担軽 減に効果的なコントローラであると同時に, 実用上危 険なシステムであるとも言える.

図 7 に矩形波状の操作力を加えた場合の応答のシ ミュレーション結果を示す. 条件は, $m=30[\mathrm{~kg}], \ell=$ $1.0[\mathrm{~m}]$, 微分ゲイン $K_{d}=0.0$ とし, $\zeta=0.707$ となる ように積分ゲイン $K_{i}$ と比例ゲイン $K_{p}$ を変化させた. 理論式どおりの搬送速度に整定し， $K_{i}$ が大きいほど高 速な搬送が実現できることが認められる.

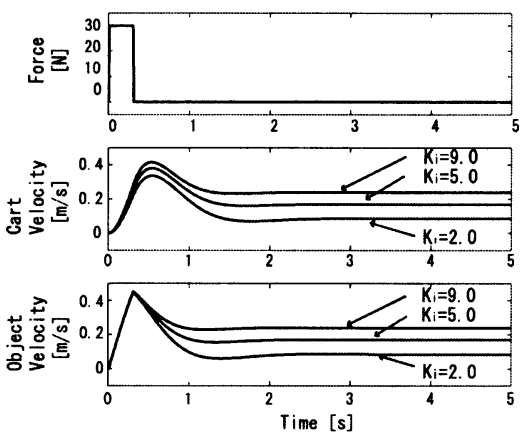

Fig. 7 Variation of transportation velocity according to $K_{i}$

3.4.3 位置決めの際の操作力 操作力を加えて いない状態で移動している荷物を手で操作し, 停止さ せる際に手が受ける力を考察する. 荷物を一定加速度 $a_{c c}\left[\mathrm{~m} / \mathrm{s}^{2}\right]$ で $T[\mathrm{~s}]$ 間減速させ停止させるとしたときに 必要な操作力は, (3) 式より,

$$
\begin{aligned}
F[s] & =\frac{m a_{c c}}{s}\left(1-e^{-T s}\right) \\
& +\frac{m a_{c c} g}{s K_{i}}\left(\frac{\frac{K_{i}}{K_{d}+\ell}}{s^{2}+\frac{K_{p}}{K_{d}+\ell} s+\frac{K_{i}}{K_{d}+\ell}}\right)\left(1-e^{-T s}\right)(16)
\end{aligned}
$$

である. 第一項は質量 $m$ の物体を減速するのに必要な 力, 第二項は減速後も停止状態を維持するために加え なければならない力を示す. すなわち, 荷物を止めた ために行き過ぎてしまった台車が荷物の真上に戻って くるまで荷物に加え続けなければならない力である. 図 8 に矩形波状の減速を行った場合のシミュレーショ ン結果を示す. 条件は, $m=30[\mathrm{~kg}], \ell=1.0[\mathrm{~m}]$, 微分 ゲイン $K_{d}=-0.5$ とし， $\zeta=0.707$ となるように積分 ゲイン $K_{i}$ と比例ゲイン $K_{p}$ を変化させた. 受け止め時 に台車速度が増しているのは負の微分ゲインの影響で ある. 操作力に関して第一項と第二項が合成された波 形が観測される.

\section{4. パワーアシストシステムの動作}

$4.1 P D$ コントローラによる実験結果ＰD コン トローラを用いて実験機による制御実験を行った. 実 験条件を以下に示す. ゲイン $K_{p}$ と $K_{d}$ は第 3.3 節の議 論をもとに，実験における観測ノイズ，モデル化誤差 の影響を考慮しながら試行錯誤によって決定した. 本 


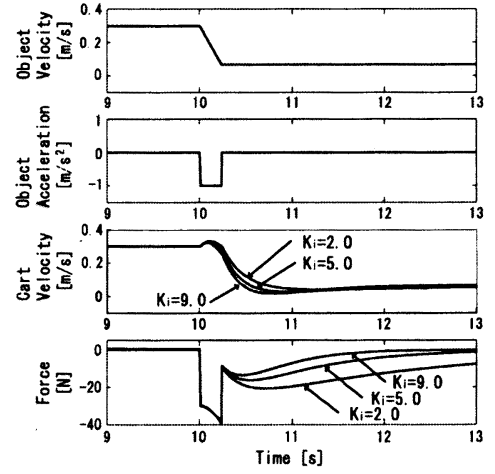

Fig. 8 Variation of transportation velocity according to $K_{i}$

例では $K_{d}$ を $\ell$ 約半分の負の值としている. これ以下 の值は観測ノイズによって正常な制御は困難であった.

Table 1 Parameters of experiment

\begin{tabular}{|l|c|c|}
\hline Parameter & unit & value \\
\hline Lope Length & {$[\mathrm{m}]$} & 1.0 \\
\hline Mass of Object & {$[\mathrm{kg}]$} & 30 \\
\hline Gain $K_{p}$ & & 5.0 \\
\hline Gain $K_{d}$ & & -0.5 \\
\hline
\end{tabular}

実験結果とシミュレーション結果の比較を図 9に示 す. 図は上から操作力, 荷物の振れ角, 台車速度, およ び台車位置を示す．操作力の計測は作業者の手と荷物 の間に装着されたロードセルによって行った. シミュ レーション結果は測定された操作力を (3) 式に与える ことによって計算された．実駼結果はシミュレーショ ン結果とよく一致しており, モデルの妥当性が確認で きる. 操作力を除去したあとの残留振動も抑制されて おり, 台車速度も 0 に収束している.

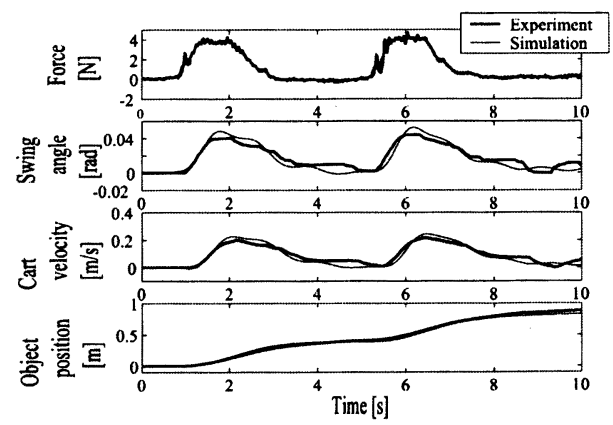

Fig. 9 Experimental result for PD controller

操作力を一定に加えた時の定常速度の実駼結果と理
論值を図 10 に示す．台車速度は操作力に比例してお り, (11) 式の理論值に一致する. 本実験により, $30[\mathrm{~kg}]$ の荷物を $3[\mathrm{~N}]$ の力で人間が歩くほどのスピード（約 $5 \mathrm{~km} / \mathrm{h}=0.14 \mathrm{~m} / \mathrm{s}$ ）でなめらかに移動させることが確認 できた.

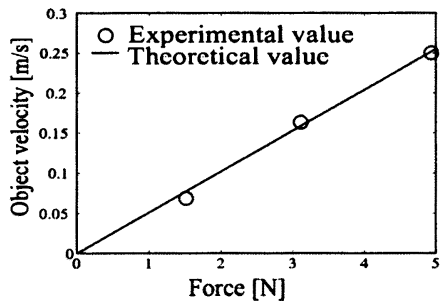

Fig. 10 Relationship between force and velocity

4.2 PID コントローラの実験結果ＰID コント ローラによる実験結果を図 11 に示す. ゲイン $K_{p}, K_{d}, K_{i}$ は (12) 式の条件が満たされるよう設定した. これを 表 2 に示す.なお, 示されていない值は PD コントロー ラと同一である.

Table 2 Parameters of controller

\begin{tabular}{|l|c|}
\hline Parameter & value \\
\hline Gain $K_{p}$ & 5.1 \\
\hline Gain $K_{i}$ & 3.0 \\
\hline Gain $K_{d}$ & -0.5 \\
\hline
\end{tabular}

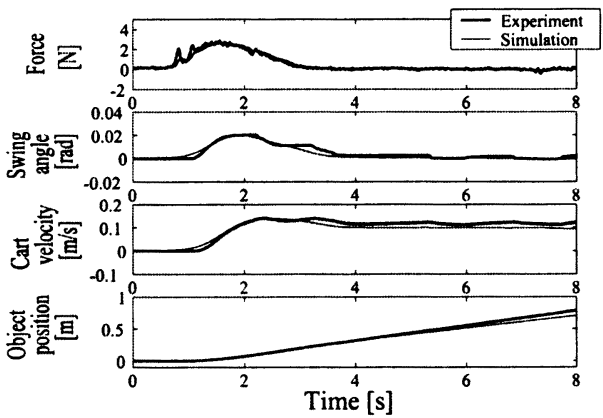

Fig. 11 Experimental result for PID controller

実験結果はシミュレーション結果によく一致してい る. 作業者の力が除去された時刻 3[s] 以降, 速やか に振れ角が 0 に収束していると同時に，台車の速度は (14) 式の值に整定している.

4.3 高次振勤モードの影第 3.3 節で示した たように, ゲイン $K_{p}$ の下限は式(7)で与えられる. 一 方，ゲインの上限はノイズなどの影響も受けるが，以 下に説明するように高次の振動モードによっても制限 される. 


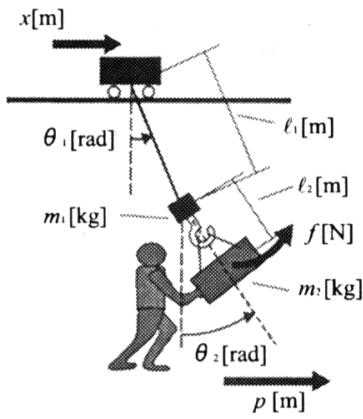

Fig. 12 Double pendulum model of power assist system

システムを近似的に図 12 のように考えると, 質点 で構成された二重振り子モデルの運動方程式は,

$$
\left\{\begin{array}{c}
M \ell_{1} \ddot{\theta}_{1}+M \ddot{x}+M g \theta_{1}+m_{2} \ell_{2} \ddot{\theta}_{2}=f \\
m_{2} \ell_{2} \ddot{\theta}_{2}+m_{2} \ddot{x}+m_{2} g \theta_{2}+m_{2} \ell_{1} \ddot{\theta}_{1}=f
\end{array}\right.
$$

で与えられる. ただし, $m_{1}$ は取り付け金具の質量 $[\mathrm{kg}]$, $m_{2}$ は荷物の質量 $[\mathrm{kg}], M=m_{1}+m_{2}, \theta_{1}, \theta_{2}$ は鉛直方 向から見たロープと荷物の振れ角で, 操作力 $f$ は $\theta_{2}$ まわりの力とする. さらに, 測定できる角度は $\theta_{1}$ の みとする. このとき, $\dot{x}=K_{f} \theta_{1}$ を代入することによっ てそれぞれの状態の関係式が得られ，比例制御の場合 は, $\theta_{1}$ は

$$
\frac{\theta_{1}[s]=}{m_{1} \ell_{1} \ell_{2} s^{4}+m_{1} \ell_{2} K_{p} s^{3}+M g\left(\ell_{1}+\ell_{2}\right) s^{2}+M K_{p} g s+M g^{2}} F[s]
$$

となる.

矩形波状の操作力を加えたときのシステムの応答を, 微分ゲインや印加時間を変化させながらシミュレーショ ンした結果を図13 に示す。なおパラメータは以下の 值とした.

Table 3 Parameters of double pendulum

\begin{tabular}{|l|c|c|}
\hline Parameter & unit & value \\
\hline mass of tool $m_{1}$ & {$[\mathrm{~kg}]$} & 1.0 \\
\hline mass of object $m_{2}$ & {$[\mathrm{~kg}]$} & 30.0 \\
\hline rope length $\ell_{1}$ & {$[\mathrm{~m}]$} & 0.8 \\
\hline tool length $\ell_{2}$ & {$[\mathrm{~m}]$} & 0.2 \\
\hline
\end{tabular}

$K_{d}$ を 0 (実線) から-0.5（破線）に変化させること で台車の振動が大きくなっている. また, 同一ゲイン であっても印加時間を $0.2[\mathrm{~s}]$ (実線) から $0.1[\mathrm{~s}]$ （一 点鎖線) に変えることで振動が大きくなる.これは, フィードバックゲイン, 特に微分ゲイン $K_{d}$ を上げる ことによって周波数特性が広帯域化するため振れ角 $\theta_{2}$ や台車速度 $\dot{x}$ の高次モードが励起されやすくなること
と, 印加時間を短くすることによって入力信号の周波 数特性が広帯域化するため, やはり高次モードが励起 されやすくなると考えられる. $K_{p}=5.0, K_{d}=0.0$ のと きの $f$ から $\theta_{1}$ に対するボード線図を図 14 に示す. 1 次振動モードはフィードバックにより抑制されている が 2 次振動モードは残っている.

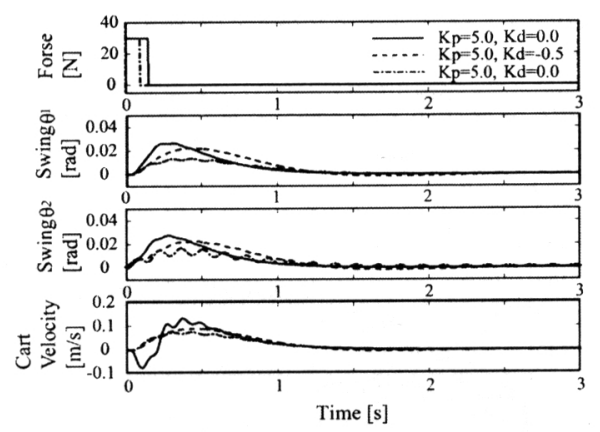

Fig. 13 Excitation of higher-order mode by short-time input in double pendulum model

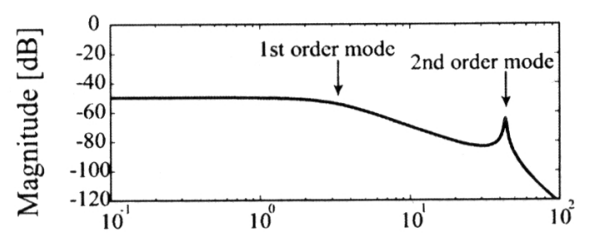

Frequency $[\mathrm{rad} / \mathrm{sec}]$

Fig. 14 Closed-loop bode diagram from $f$ to $\theta_{1}$ in double pendulum model

実際のクレーンシステムでは荷物や台車の振動は 極めて危険であるため,このようなフィードバックゲ インの設定は認められない. よってゲインは高次振動 モードを励起しないような值に定める必要がある.

\section{5. パワーアシストによる負荷の軽減の定量的評価}

パワーアシストによる負荷の軽隇がどの程度である かを, 作業者の心拍数により定量的に評価した実験結 果を図 15 に示す.これは, 人間の運動強度 $[\mathrm{W}]$ と心 拍数 $[\mathrm{bpm}]$ (beat per minutes) は激しい運動でなければ 比例する ${ }^{(13)}$ との知見に基づき, 作業者の負担を心拍数 により評価するものである.

実験方法は, $20[\mathrm{~kg}]$ の荷物を $20[\mathrm{~s}]$ で $1.5[\mathrm{~m}]$ 移動さ せ，これを 15 回，都合 $300[\mathrm{~s}]$ 間繰り返し，その間の心 拍数の変化をパワーアシストなし（人力による搬送）, PD コントローラによるパワーアシスト, PID コント ローラによるパワーアシスト, の三種類で比較した. 
被験者としては日本人の平均的な体格を持つ 20 代の 健康な男性を採用した. $300[\mathrm{~s}]$ の実験時間は, 人間の 心拍数は軽度の運動に対して通常約 3 分程度で定常状 態に整定することに由来する.

図 15 において Hard anearobics（無酸素運動）とは 長時間継続できないほどの強い運動を意味し, Easy anearobics とはジョギングなどの肉体にストレスを与 える適度な運動を示す.さらに, Hard earobics（有酸 素運動）とは体操などの軽いウオームアップ程度の運 動を示し, Easy earobics とは, 日常生活と同程度の運 動を示す.

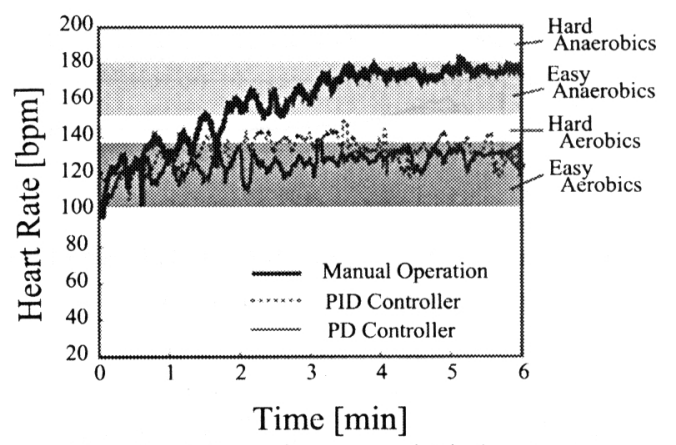

Fig. 15 Effect of power assist in heart rate

明らかに, パワーアシストシステムは大きく作業者 の負担軽減に寄与し, 日常生活程度の負荷に減少して いることがわかる. 一方, 定速移動時に操作力の必要 な PD コントローラと不必要な PID コントローラでは, パワーアシストの効果に有意な差は認められない.こ れは必要な操作力が数 $[\mathrm{N}]$ とごく軽微なためと考えら れる.

\section{6. 結 論}

天井クレーンにおいて, わずかな操作力で作業者の 意図する方向に重量物を移動できるパワーアシストシ ステムの構築を行った. 本システムは, 荷物が押され た際に生じるわずかな振れ角をフィードバック制御す ることで実現される. パワーアシストシステムの定式 化が行われ, PD 制御では操作力に比例した速度で荷 物が移動できること, PID 制御では操作力の除去後も 荷物が移動することが明らかにされ, 理論值と実験結 果との一致が確認された. また, 荷物の残留振動や高 次モードの振動の生じない適切なフィードバックゲイ ンの範囲が明らかにされた. 最後に, パワーアシスト による作業者の負担の軽減が評価され, 本提案手法の 有効性が確認された.

\section{7. 付 録}

[証明] 初期状態が 0 で, かつ有限の時刻 $T$ で 0 に 収束する関数 $f(t)(t=0, T<t$ で $f(t)=0)$ において, $F_{o}[s]$ を $f(t)$ の原始関数のラプラス変換とすると,

$$
\lim _{s \rightarrow 0} F[s]=\lim _{s \rightarrow 0} s F_{o}[s]=\int_{0}^{\infty} f(t) d t=\int_{0}^{T} f(t) d t
$$

謝辞

本研究は豊橋技術科学大学未来技術流動研究セン ターの若手研究者プロジェクト助成の支援を受けて行 われた。ここに感謝の意を表す。

\section{文献}

(1) 山本元司, 柳井法貴, 毛利彰, 多自由度クレーン型マニュ ピレータの逆動力学計算と軌道制御, “日本ロボット学 会誌”, Vol.17, No.7, (1999), pp.1037-1043

（2）柳井法貴, 山本元司, 毛利彰, 逆動力学計算に基づくク レーンのフィードバック制御, “計測自動制御学会論文 集”, Vol.1, No.1, (2001), pp.1-8

（3）鈴木薪雄, 寺嶋一彦, 障害物回避と振れ止めのためのク レーンのセミオート制御, “日本機械学会論文集 (C)”, 67(660), (2001), pp.149-156

（4）高木清志, 西村秀和, タワークレーンの吊り荷ロープ長 変動に対する起伏・旋回方向のゲインスケジュールド 分散制御 操綐者の任意指令に対応する制御系設計, “日本機械学会論文集 (C)”, 69(680), (2003), pp.914-922

(5) 前田裕史, 藤原茂喜, 北野斉, 山下秀樹, 全方向移動型パ ワーアシストカートの開発, “18回日本ロボット学会学 術講演会予稿集”, Vol.18, No.3, (2000), pp1155-1156

(6) 數下英典, 平田泰久, 小菅一弘, パワーアシスト自転 車の走行抵抗可変型制御, “日本機械学会論文集 $(C)$, 69(680), (2003), pp.1031-1036

(7) 藤江正克, 自立歩行システム, “計測と制御”, Vol.40, No.5, (2001), pp.384-387

(8) 西坂晋, 北川秀夫, 三好孝典, 寺嶋一彦, 全方向移動電動 車椅子における介助者用パワーアシストシステムの構 築, “ロボティクス・メカトロニクス’03 講演会論文集”, (2003), 2P2-2F-D2

(9) 中村久, 運搬用パワーアシストシステムの開発,“シス テムインテグレーション部門学術講演会”01 講演論文 集”, (2001), pp.515-516

(10) Y.Yamada, H.Konosu, T.Morizono, YUmetani, Proposal of Skill-Assist: A system of Assisting Human Workers by Reflecting Their Skill in Positing Tasks, "Proc. IEEE Int Conf. Systems", Man and Cybernetics, (1999), pp.IV11IV 16

(11) P Akella, Cobots for the automobile assembly line, "Proc. IEEE Int Conf. Rob. Autom.", (1999), pp.728-733

(12) Kemin Zhou, John C.Doyle, Keith Glover, Robust and Optimal Control, Prentice Hall, (1995), pp.112-113

(13) Olof Astrand, Kaare Rodahl, オストランド運動生理学, 大修館書店, (1976), pp.204-235 